observed when mice were treated with the same materials. When $0.2 \mathrm{ml}$. of the phenol extract of the mouse-virulent strains were injected into the tail veins of mice, $50 \mathrm{per}$ cent died within $12 \mathrm{~h}$. The survivors did not succumb when challenged intravenously with 10 million colls of the homologous strain, a uniformly lethal dose in unprotected controls. Corresponding doses of the ethanolethyl other extracts were not lethal to mice; but all animals so treated were severely ill for at least 2 days and subsequent challenge with the number of yeasts fatal to unprotected controls failed to kill. The mouse-avirulent strain did not elicit any response in controls nor did extracts and extracted cells produce any ill effects. These findings, which are summarized in Table 1, suggest that material resembling endotoxin is elaborated by strains of Candida albicans virulent to mice.

We thank Dr. Edgar Ribi, U.S. Public Health Service, Rocky Mountain Laboratory, Hamilton, Montana, for advice.

This work was supported by the Office of Naval Research contract $N R \quad 103--523$.

Department of Laboratorios,

HENRY D. ISENBERG

JoNa Allerhand

JAMES I. BERKMAN

The Long Island Jewish Hospital,

New Hyde Park, New York.

${ }^{1}$ Stetson, C. A., in Cellular and Humoral Aspects of the Hypersensitivity States, edit. by Lawrence, H. S., 442 (Hoeber-Harper, New York, 1959). 2 Salvin, s. B., J. Immunol., 69, 89 (1952).

${ }^{3}$ Hasenclever, H. F., and Mitehell, W. O., Bact. Proc. (1962); and jersonal communication.

'Ribi, E., Haskins, W. T., Iandy, M., and Milner, K. C., Bact. Rer., 25. $27(1901)$

'Westphal, O., and Luderitz, O., Angew. Chem., 66, 407 (1954).

\section{Cytochromes of Pseudomonas saccharophila}

LiQUID cultures of autotrophically grown Pseudomonas saccharophila ${ }^{1}$ are pink and when gassed with hydrogen the colour is intensified. On examination of spectra of cells reduced with hydrogen, using a Cary No. 11 recording spectrophotometer and the opal glass technique ${ }^{2}$ the difference spectra showed a Soret band, flavin trough and a single peak at $550 \mathrm{~m} \mu$. Breaking the cells and fractionat. ing the extract into a soluble fraction and washod small particlos ${ }^{1}$, resulted in finding a spectra characteristic of a eytochrome $c$ in the soluble fraction and the presence of cytochromes of the $b$ and $c$ type in the particles. Comparison of the optical density of roduced-oxidized preparations at $550 \mathrm{mu}$, shows the distribution of cytochrome $c$ to be 77 per cent in the soluble fraction and 23 per cent associated with particles. Difference spectra of the particles are shown in Fig. 1. No other eytochrome peaks were ever observed in cells and extracts of $P$. saccharophila. Hand spectroscopic examination of particles in 50 per cent glycerol at the temperature of liquid nitrogen, as described by Keilin and Hartree ${ }^{3}$, showed only three bands, one ascribed to cytochrome $b$ and the other two due to the splitting of the cytochrome $c \alpha$-band into two components. The two bands for cytochrome $c$ were also observed with partially purified cytochrome $c$ from the soluble fraction. Packer ${ }^{4}$ examined another hydrogen bacterium, Hydrogenomonas ruhlandii and only found a cytochrome $b$ and $c$ in whole cells.

On fractionating tho solublo oxtract with ammonium sulphate, 18 per cont of cytochrome $c$ precipitated in the 80-100 per cent saturated ammonium sulphate fraction and the rest was soluble in saturated ammonium sulphate solution. Tho second fraction was dialysed and lyophilized. Absorption maxima for this fraction were 550,523 and $417 \mathrm{m \mu}$ and in the case of the pyridine hæmochromogen 550,521 and $417 \mathrm{~m} \mu$. Redox potential was measured using a ferrous-ferric oxalate couple ${ }^{5}$ and $E^{\prime}{ }_{0}$ at $p H$ 7.8 was $+0.08 \mathrm{mV}$. This cytochrome $c$ preparation is slowly autoxidized. Only two other cytochromo c's have been

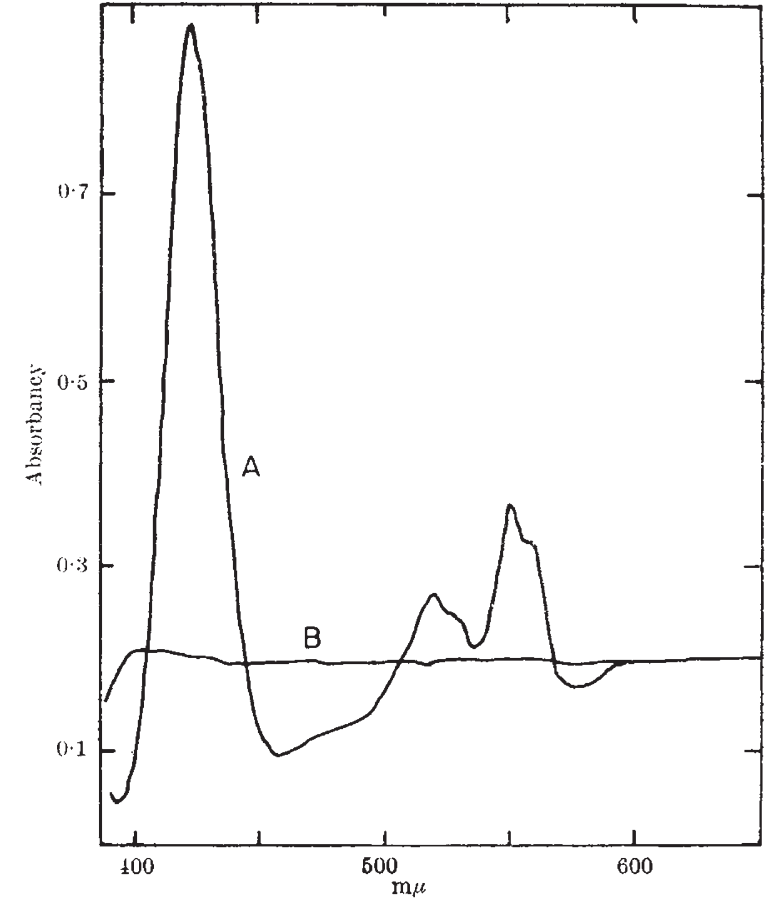

Fig. 1. Difference spectra of washed small particles. Curve $A$, particles reduced with hydrogen-oxidized particles. Curve $B$, reduced particles$12 \mathrm{mg}$ of dry weight of cells

observed with lowor redox potentials, that of Chromatium which has 2 hæm groups ${ }^{6}$ and Desulfovibrio desulfurican: which has 2 hiem groups per molecule? The other unusual property of eytochrome $c$ of $P$. saccharophila is solubility in saturated ammonium sulphate solution which has also been observed with cytochrome $b_{3}$ of higher plants ${ }^{8}$.

Department of Microbiology,

D. H. Bonk:

Yale University,

New Haven, Connecticut.

* Present address: Department of Botany, Queen Mary College. liniversity of London, London, $\mathrm{x} .1$.

${ }^{1}$ Bone, D. H., Biochem. Biophys. Res. Comm., 3, 211 (1960).

${ }^{2}$ Shibata, K., Benson, A. A., and Calvin, M., Biochim. Biophys. Att 15 461 (1954).

${ }^{3}$ Keilin, D., and Hartree, E. F., Nature, 164, 254 (1949)

4 Packer, L., Arch. Biochem. Biophys., 78, 54 (1958).

- Hill, R., Nature, 174, 501 (1954).

"Bartsch, R. G., and Kamen, M. D., J. Biol. Chem., 235, 825 (tofit).

' Postgate, J. R., J. Gen. Microbiol., 14, 545 (1956).

${ }^{8}$ Hill, R., and Scarisbrick, R., New Phyt., 50, 88 (1951).

\section{Physical and Chemical Properties of Two New Small Bacteriophages}

In recent years, several investigators have reported new bacteriophages which have a molecular weight about 100 times less than the classical $T$-scries of phages ${ }^{1,2}$. Those? small phages which have been physically characterized are roughly spherical and have a molecular weight of $4-6 \times 10^{6}$, of which $20-30$ per cent is nucleic acid. 'The nucleic acid is either single-stranded $\mathrm{DNA}^{3}$ or $\mathrm{RN} \mathrm{N}^{2}$.

We have been studying two small phages which infect only male ( $F^{+}$or $H f r$ ) strains of bacteria. The phages were isolated from sewage and grown and purified using con. ventional methods. Both phages are resistant to DNast: and RNase. One of the phages $(f r)$ contains RNA and seems in many respects similar to $f 2$ phage ${ }^{2}$. The other ( $f d$ ) contains single-stranded DNA. It seems to have an unusual physical form.

The fr phage is spherical in electron micrographs, with a diameter of $200-220 \AA$. Its physical properties in solution are given in Table I. Its molecular weight is calculated as 